\title{
An overlap of antineutrophil cytoplasmic antibody-associated vasculitis and IgG4-related disease: distinct clinicopathologic clues for precise diagnosis
}

Peifen Liang ( $\square$ lpeif@mail.sysu.edu.cn )

Sun Yat-Sen Memorial Hospital https://orcid.org/0000-0002-7866-6123

Wenfang Chen

Sun Yat-sen University First Affiliated Hospital

Shuling Yue

Guangzhou KingMed Center

Qianqian Han

Sun Yat-Sen Memorial Hospital

Litong Zhu

Sun Yat-Sen Memorial Hospital

Jinggao Li

Sun Yat-Sen Memorial Hospital

Qiongqiong Yang

Sun Yat-Sen Memorial Hospital

Research Article

Keywords: antineutrophil cytoplasmic antibody-associated vasculitis, IgG4-related disease, myeloperoxidase-anti-neutrophil cytoplasmic antibody, overlap syndrome, tubulointerstitial nephritis

Posted Date: April 6th, 2021

DOI: https://doi.org/10.21203/rs.3.rs-161443/v1

License: (c) (1) This work is licensed under a Creative Commons Attribution 4.0 International License. Read Full License 


\section{Abstract}

Background: Both antineutrophil cytoplasmic antibody (ANCA)-associated vasculitis (AAV) and IgG4-related disease (IgG4-RD) are multi-system inflammatory disorders. The coexistent of both diseases present the possibility of a new overlap syndrome which leads to different treatment and outcome. In this study, we aim to investigate the possibility and clinicopathologic clues to the diagnosis of this overlap syndrome.

Methods: A case of a 67-year-old man in our hospital who exhibited the clinicopathologic characteristics of both AAV and IgG4-RD was presented. The serial alterations in serum parameters and treatment response of the case were followed up for the next 15 months. Then, a systematic literature review of the overlap syndrome was performed on PUBMED database from 1976 until January 2020.

Results: Forty-two patients fully met both AAV and IgG4-RD criteria in the literature. The median age was 60 years ranged from 31 to 73 years at diagnosis. Twenty-eight (66.7\%) patients were men. Serum IgG4 concentration increased in 41 (97.6\%) patients (median:395 mg/dl; range:177-876mg/dl). Forty-one patients (97.6\%) tested positive for ANCA with 37 (90.2\%) patients showing a specificity for MPO. Kidney histology of 23 (69.7\%) patients presented pauciimmune necrotizing or crescentic glomerulonephritis and IgG4-related tubulointerstitial nephritis. Glucocorticoids combined with cyclophosphamide therapy was commonly prescribed with a high remission rate within 3 months. Four common clinicopathologic features of the overlap syndrome were identified from the case and literature.

Conclusion: AAV may overlap with IgG4-RD while presenting atypical manifestations. Four common clinicopathologic characteristics could be used as specific clues to the diagnosis of overlap syndrome.

\section{Background}

Antineutrophil cytoplasmic antibody (ANCA)-associated vasculitis (AAV) is a disorder categorized under necrotizing vasculitis, which predominantly affects small vessels with few or no immune deposits [1]. The main target antigens in patients with AAV are myeloperoxidase (MPO) and proteinase 3 (PR3) [1]. AAV is subdivided into microscopic polyangiitis (MPA), granulomatosis with polyangiitis (Wegener) (GPA), and eosinophilic granulomatosis with polyangiitis (Churg-Strauss) (EGPA) [1].

Immunoglobulin G4-related disease (IgG4-RD) is an immune-mediated fibro-inflammatory disorder characterized by tumefactive lesions, a dense lymphoplasmacytic infiltrate rich in IgG4-positive plasma cells, storiform fibrosis, and, often but not always, elevated serum IgG4 concentrations [2]. Clinically apparent renal involvement occurs in approximately $15 \%$ of patients [3], and is termed as IgG4-related kidney disease (IgG4-RKD). Tubulointerstitial nephritis (TIN) is the most common manifestation of IgG4-RD in the kidney which defined as IgG4-related TIN [4].

Both AAV and IgG4-RD are autoimmune-mediated multi-system disorders, suggesting a potential association between these two disease entities. Recently, increased IgG4 + cells had been seen in tissue biopsies of GPA patients [5] and ANCA positive IgG4-RD has been observed. The coexistent of AAV and IgG4-RD with clinical and/or histological evidence of both diseases had been proposed as a new overlap syndrome by a few researches since 2017 [6,7]. However, this suggestion has received a myriad of different opinions since IgG4-RD shares a large spectrum of features with AAV, which can clinically and histopathologically mimic IgG4-RD [8]. Yoo et al argued that elevated serum IgG4 may simply reflect the activity and inflammatory burden of AAV during diagnosis in a retrospective study including 139 patients with MPA and GPA but only 33.1\% with results on serum IgG4 [9]. Meanwhile, Erden et al proposed that the existing findings that these two diseases overlapped was perhaps a synergy in the laboratory rather than an overlap [10]. Therefore, whether the concomitance presented between AAV and IgG4-RD is actually the manifestation of an overlap syndrome remains controversial. As treatment and prognosis are different between both diseases, distinction of the overlap syndrome remains essential. Especially when AAV is missed due to an overlapped diagnosis of IgG4-RD, it will probably cause significantly poor outcomes.

Hence, we present a case with coexistence of biopsy-proven AAV manifested as MPO-ANCA-associated crescentic glomerulonephritis and IgG4-related tubulointerstitial nephritis, in which serial alterations in serum IgG4 and MPO-ANCA were traced. Furthermore, we also provide a comprehensive literature review on the common clinicopathologic characteristics of the overlap syndrome, to find out specific clues to the diagnosis providing better understanding for the special and rare entity.

\section{Methods}

\section{Patient and data collection}

A 67-year-old man that exhibited the characteristics of both AAV and IgG4-RD was admitted in our hospital on September 7, 2018. The clinical and laboratory data of the patient was collected, and the treatment response and outcomes were followed up for 15 months. A systematic literature review base on biopsy was then performed using PUBMED database covering the time period from 1976 until January 2020. The patients who met both AAV and IgG4-RD criteria as overlap syndrome would be included. AAV was defined by the 2012 Chapel Hill Consensus Conference nomenclature criteria [1]; while IgG4-RD diagnosis was based on the comprehensive diagnostic criteria [11] and IgG4-TIN was defined by the criteria set by Mayo Clinic [12]. According to the criteria, the definite diagnosis of IgG4-RD was defined by the following 3 criteria: (1) clinical examination showing characteristic diffuse or localized swelling or masses in single or multiple organs; (2) elevated serum IgG4 concentrations (>135 mg/dL); (3) histopathological examination showing: (I) marked lymphocyte and plasmacyte infiltration and fibrosis; (II) infiltration of IgG4 + plasma cells: ratio of IgG4+/lgG + plasma cells > 40\% and > 10 lgG4 + plasma cells per high-power field (HPF). Results were restricted to studies in human and articles written in English language. Articles without histopathological information or detail data were excluded. This study was approved by the Ethics Committee of the Sun Yat-sen Memorial Hospital, Sun Yat-sen University (SYSEC-KY-KS-2020-080-001). 
Statistical analysis was performed with SPSS 19.0 (IBM, Armonk, NY, USA). Continuous variables were expressed as a mean \pm standard deviation, and categorical variables were expressed as a number (percentage).

\section{Results}

\section{Case presentation}

A 67-year-old man was admitted to our hospital complaining of repeated cough, hemoptysis, anorexia and fatigue. He has a significant medical history for hypertension and was a heavy smoker. Five months prior to admission, the patient was diagnosed with pneumonia at the local hospital on the basis of cough, hemoptysis and diffuse lesions in both lungs that were observed through the chest computed tomography (CT) scan. At that time, his serum IgG was 16.35 $\mathrm{g} / \mathrm{L}$ (normal range: 7-16 g/L), while his hemoglobin, serum creatinine and C-reactive protein (CRP) levels were in the normal range. In addition, urinalysis yielded negative results for proteinuria and hematuria. Two months before admission, he experienced ear stuffiness due to mixed hearing loss, after which a CT scan revealed bilateral middle ear mastoiditis, bilateral ethmoid sinusitis. The month before admission, he complained about anorexia and fatigue, and developed severe anemia with hemoglobin concentration at only $59 \mathrm{~g} / \mathrm{L}$. Rapid deterioration of renal function was observed with serum creatinine level at $717.2 \mu \mathrm{mol} / \mathrm{L}$. The test for serum anti-MPO antibody showed positive result, while anti-PR3 antibody was weakly positive. The diagnosis of AAV was made and methylprednisolone $40 \mathrm{mg} / \mathrm{d}$ was prescribed. Serum creatinine level decreased to $548.1 \mu \mathrm{mol} / \mathrm{L} 6$ days after treatment.

Later on, the patient was admitted to our hospital. Doppler ultrasound examination revealed that the mean length of the left kidney amounted to $90.4 \mathrm{~mm}$, and the right kidney $104.4 \mathrm{~mm}$. CT scan showed right maxillary sinusitis and multiple subpleural small nodules (approximately 2 to $3 \mathrm{~mm}$ in diameter) could be seen in both lungs (shown in Fig. 1. A, B). The right upper lung had shown inflammation, while bilateral ground-glass opacity was displayed by the lower lung (shown in Fig. 1. C). Serum IgG was $19.7 \mathrm{~g} / \mathrm{L}$ (normal range:7-16 g/L), IgG4 was $4.07 \mathrm{~g} / \mathrm{L}$ (normal range: $0.030-2.010 \mathrm{~g} / \mathrm{L}$ ), and the lgG4: IgG ratio was 20.7\%. Serum IgE was $406 \mathrm{IU} / \mathrm{mL}$ (normal range: 0-100 IU/mL) and CRP was $12.6 \mathrm{mg} / \mathrm{L}$ (normal range: < $5.0 \mathrm{mg} / \mathrm{L}$ ). No hypocomplementemia was apparent, with C3 and C4 levels at 790 and $147 \mathrm{mg} / \mathrm{L}$, respectively. The levels of serum creatinine was $481 \mu \mathrm{mol} / \mathrm{L}$ (normal range: $44-133 \mu \mathrm{mol} / \mathrm{L}$ ), urinary red blood cells 6 to 10/high-power field, urine microalbumin $129.0 \mathrm{mg} / \mathrm{L}$ and 24-hour urine protein quantitation at 0.16 to $0.32 \mathrm{~g}$. Peripheral white blood cells were 8.97 $\mathrm{x} 10^{9} / \mathrm{L}$ with normal eosinophils, and hemoglobin was $89 \mathrm{~g} / \mathrm{L}$. A test for serum perinuclear-ANCA had shown positive result, and MPO-ANCA level was 275.27 $\mathrm{U} / \mathrm{mL}$ (normal range $0-15 \mathrm{U} / \mathrm{mL}$ ). The PR3-ANCA level was $2.181 \mathrm{U} / \mathrm{mL}$ (normal range $0-15 \mathrm{U} / \mathrm{mL}$ ). A renal biopsy was then performed with the following results: immunofluorescence examination showed fibrinoid necrosis, IgM (+) and C3 (+/-), tubular basement membrane (TBM) deposits showed granular staining for IgG (shown in Fig. 2. A); under light microscopy, fifteen glomeruli could be seen in the specimen, among which two were observed with cellular crescents and eight with cell fibrotic crescents (shown in Fig. 3. A); multifocal inflammatory cell infiltration was evident in the tubulointerstitial area (shown in Fig. 3. B). Immunohistochemical staining showed that IgG4 positive plasma cells were more than 10/HPF, and the ratio of IgG4-positive to IgG-positive plasma cells was more than $40 \%$ (shown in Fig. 3. C, D). Ultrastructural examination reveals electron-dense deposits, without substructure, in the TBM (shown in Fig. 2. $B, C)$

The patient was finally diagnosed with IgG4-RD based on the IgG4-positive plasma cell-enriched TIN, increased serum IgG4, TBM deposits and pulmonary nodules. The findings of pauci-immune crescentic GN, ground-glass opacities in the lower lungs, middle ear mastoiditis, paranasal sinusitis and increased MPO-ANCA led to a concurrent diagnosis of systemic ANCA-associated vasculitis in the form of MPA (shown in Table 1). The patient received methylprednisolone pulse therapy of $0.5 \mathrm{~g} / \mathrm{d}$ for 3 consecutive days followed by $40 \mathrm{mg} / \mathrm{d}$ intravenous drip. Later, oral prednisone was tapered to $20 \mathrm{mg} / \mathrm{d}$ due to complication of pulmonary inflammation. The patient responded partially to this regime of treatment. His serum creatinine and IgG level decreased to 319 $\mu \mathrm{mol} / \mathrm{L}$ and $10.4 \mathrm{~g} / \mathrm{L}$ respectively; while his serum IgG4 and $\mathrm{lgG} 4$ : IgG ratio dropped to $1.53 \mathrm{~g} / \mathrm{L}$ and $14.71 \%$ respectively.

Four months later, re-examination through CT showed improvement in bilateral interstitial changes (shown in Fig. 1. D), but ground-glass nodules were still seen in the right middle lobe with multiple subpleural small nodules. However, the bronchial lavage fluid examination revealed no evidence of fungus or tuberculosis. Changes in the lungs were thought to be caused by IgG4-RD, but biopsy could not be performed due to the location of upper lobe and the high risk it bears. After 6 months of treatment, the level of serum IgG4 was $0.323 \mathrm{~g} / \mathrm{L}$, and serum creatinine was maintained at $230 \mu \mathrm{mol} / \mathrm{L}$ (shown in Fig. 4). Five months ago, the patient received intravenous cyclophosphamide at 0.2-0.4 g every two weeks in local hospital. His latest serum creatinine level was at 187.2 $\mu \mathrm{mol} / \mathrm{L}$. Regular follow-up is still ongoing.

\section{Literature review}

\section{Clinical profile}

Through the literature review (from 1976 to 2020), 52 patients who met IgG4-RD and AAV criteria based on histopathological investigation were identified, which were defined as having overlap syndrome according to the previous researches [6,7]. 10 patients without detailed data were excluded [6] and 42 patients were included. Among them, 34 cases showed concurrent IgG4-RKD and AAV, and 29 cases (85.3\%) were IgG4-RKD concomitant AAV associated glomerulonephritis (ANCA-GN) with mild to moderate renal impairment (shown in Table 2-3).

Among the 42 patients ranged in age from 31 to 73 years old with a median age of 60 at diagnosis, 14 (33.3\%) patients were women, and 28 (66.7\%) patients were men. Serological tests of CRP were showed in 20 patients. 16 of them (80.0\%) has an elevated level of CRP ranging from 2.11 to $17.9 \mathrm{mg} / \mathrm{dl}$. Serum IgG4 concentration increased in 41 (97.6\%) patients (median:395 mg/dl; range:177-876mg/dl). Forty-one patients (97.6\%) tested positive for ANCA with 37 (90.2\%) patients showing a specificity for MPO and 4 (9.8\%) patients with a specificity for PR3. The identification of IgG subclasses of MPO-ANCA was performed in three studies involving 17 patients [15-17] and all patients were positive for IgG4-MPO-ANCA in overlap syndrome. The main organs involved in both AAV and IgG4-RD are kidney and lung. The ear, nose and throat (ENT) and peripheral nervous system (PNS) involvement were prevalent in AAV (21.4\%, 19.0\%, respectively), while pancreas involvement appeared mainly in IgG4-RD cases (9.5\%) (shown in Table 2-3).

Page 3/13 
In the 34 patients with concurrent IgG4-RKD and AAV, the average of serum creatinine level was $302.7 \pm 193.5 \mu$ mol/L. In 15 patients with recorded proteinuria level, 14 exhibited $\sim 2 \mathrm{~g} /$ day proteinurea level, with no nephrotic syndrome. Microhematuria was either absent or low in most patients (0-15 erythrocytes/high power field in light microscopy of urine sediments) (Table 3).

\section{Pathological profile}

A total of 48 biopsies were performed in 42 patients. The biopsy site with the highest frequency was the kidneys (75.0\%), followed by the lungs ( $8.3 \%$ ). Evidence of necrotizing vasculitis lesions, leukocytoclastic vasculitis lesions and necrotizing granulomatous inflammation was respectively observed in 3 patients, while necrotizing glomerulonephritis in 9 patients, and crescentic glomerulonephritis in 12 patients. Lymphoplasmacytic infiltrate was noted in all IgG4-RD patients, with an IgG4/lgG ratio of $>40 \%$ in 8 (19.0\%) patients and the number of IgG4-positive plasma cells $>10$ per HPF was observed in 33 (78.6\%) patients. Storiform fibrosis was present in 23 (54.8\%) patients (shown in Table 2-4).

Regarding to the 33 patients manifested as IgG4-RKD and ANCA-GN overlap syndrome, kidney histology presented pauci-immune necrotizing or crescentic glomerulonephritis and IgG4-related TIN. IgG4-related TIN could be seen in all the cases. Typical storiform fibrosis was noticed in 16 (48.5\%) patients. Pauciimmune necrotizing and or crescentic glomerulonephritis could be diagnosed in 23 (69.7\%) patients. Glomerulonephritis with crescents or segmental necrosis was presented in 10 patients (30.3\%). Among these specimens, the average percentage of crescents were $39.1 \pm 20.8 \%$. Fibrinoid necrosis could be seen in 15 (45.5\%) specimens. Most immunoglobulins and complements could not be detected along the glomerular capillary loops by immunofluorescence test. Based on the ANCA-GN classification proposed by Berden et al. [18], 23 patients with available data were classified respectively as follows: 9 (39.1\%) focal, 12 (52.2\%) crescentic, 1 (4.3\%) sclerotic and 1 (5.3\%) mixed ANCA-GN (shown in Table 4).

\section{Treatment and outcome}

From the data, 42 patients received immunosuppressive therapy, among which 7 (16.7\%) patients were treated with oral glucocorticoids alone, 30 ( $71.4 \%)$ patients with glucocorticoids in combination with cyclophosphamide, $3(7.1 \%)$ patients with glucocorticoids in combination with rituximab, and $\mathrm{t} 2$ (4.8\%) patients w with oral glucocorticoids in combination with azathioprine. Additionally, 22 (52.4\%) patients received intravenous methylprednisolone pulse therapy and 5 (11.9\%) patients received additional plasmapheresis. 3 (7.1\%) patients experienced relapse of AAV or treatment resistance during treatment with glucocorticoids in combination with cyclophosphamide or azathioprine, and were then being treated with rituximab and achieved remission thereafter. During follow-up, 36 (85.7\%) out of 42 patients achieved remission within 3 months, while relapse occurred in 2 (4.8\%) cases. Treatment resistance occurred in 6 (14.3\%) patients, with 5 of them proceeded to routine hemodialysis. No fatality was recorded. In regards to IgG4-RKD, 30 (88.2\%) out of 34 patients achieved renal improvement with lower serum creatinine levels as serum IgG4 concentration decreased (shown in Table 2-3).

\section{Discussion}

In this study, we describe a patient with biopsy-proven pauci-immune crescentic GN due to MPO-ANCA positive AAV can also have IgG4-RKD based on histopathology, which is defined as overlap syndrome according to the criteria for both AAV and IgG4-RD diseases. It's worth noting that serum IgG4 elevation and IgG4-positive cell infiltration in the tissue could be seen in some cases of crescentic glomerulonephritis of AAV highlighted by Kawashima et al [7]. This is consistent with a view of that serum IgG4 might not be associated with concurrent IgG4-RD but showed activity and inflammatory burden of MPA and GPA proposed by Yoo et al [9]. It should be pointed out that no patients fulfilled comprehensive diagnostic criteria for lgG4-RD requiring IgG4+/lgG + cells $>40 \%$ or IgG4 + cells/HPF > 10 on the tissues in their AAV research [9]. The absence of TBM immune complex deposits by immunofluorescence will help underline the AAV when compared with IgG4-RKD[29]. Despite these considerations, our case and others shown in the literature review found some patients could meet the Chapel Hill Consensus Conference nomenclature criteria for AAV and comprehensive diagnostic criteria for IgG4-RD or Mayo Clinic proposed criteria for IgG4TIN, which were classed as overlap syndrome.

Although AAV and IgG4-RD can be distinguished based on characteristic findings in many cases, the diagnosis can be unclear in some cases, in which the possible coexistence of AAV and IgG4-RD should be considered. From the comprehensive literature review on biopsy-proven co-existing AAV and IgG4-RD, we identify four common clinicopathologic features of the overlap of AAV and IgG4-RD.

First of all, atypical clinical and laboratory manifestations were characteristics of this entity. As shown in Table 1 obtained from our case, atypical organ involvement, such as ENT and PNS in IgG4-RD, and lacrimal or salivary gland and pancreas in AAV, would often indicate the other commitment disease. On the other hand, our case and 14 out of 15 patients in the literature review exhibited negligible to moderate proteinurea level ( 0 to $2 \mathrm{~g} / \mathrm{day})$, with absent or low microhematuria in AAV. It suggested that unusual manifestations such as absent or mild urine sediments in AAV associated crescentic GN, or granulomatous inflammation in IgG4-RD, would also usually point to the coexistence of another disease. As for inflammation marker, elevated serum CRP was identified in the case study and $80 \%$ of the patients from the literature review demonstrated a tendency of slightly higher CRP level as compared to typical IgG4-RD cases, which is consistent with a previous study [2]. Atypical clinical and laboratory manifestations are often the first clue for clinicians when performing further workup.

Secondly, positive MPO-ANCA are more common in the overlap syndrome. Our literature review found that most patients had positive ANCA, and up to $89.8 \%$ of patients showed a specificity for MPO, while $9.8 \%$ patients with a specificity for PR3, which was consistent with our case and previous research [15,16]. The IgG isotypes are predominant in ANCA, particularly represented by IgG1, IgG3 and IgG4 subclasses [30]. IgG4-ANCA was assumed to contribute to both the correlation between serum IgG4 and the inflammatory markers, and between serum IgG4 and the activity of MPA and GPA [9]. It was hypothesized that IgG4MPO-ANCA produced by infiltrating IgG4-positive plasma cells might be responsible for the necrotizing crescentic GN [17].

Thirdly, histological patterns could overlap in the same tissue samples when kidneys are involved. Biopsy is important for the diagnosis of the overlap syndrome. AAV histological findings is characteristic of vasculitis and/or granulomatous inflammation, along with fibrosis and/or lymphoplasmacytic 
infiltration up to a certain level [1]. While the key features of IgG4-RD histology include the presence of dense lymphoplasmacytic infiltrate, storiform fibrosis and obliterative phlebitis [4]. In our case, pauci-immune crescentic GN and IgG4-positive plasma cell-enriched TIN pointed the characteristics of the histological patterns of both AAV and IgG4-RD on the biopsy specimen from the kidney. Consistent with the literature, we found that TIN is the most common renal pathological manifestation of IgG4-RKD in the overlap syndrome. Meanwhile, pauci-immune necrotizing and crescentic glomerulonephritis were the main pathological manifestation of AAV.

Finally, treatment often requires the combination of glucocorticoids and immunosuppressive therapy targeting both conditions. Glucocorticoids are currently the first-line treatment for IgG4-RD [4]. Glucocorticoids alone was prescribed in our patient due to Infectious complications for 6 months. Although the renal function was improved quickly in 1 month as the levels of MPO-ANCA and IgG4 decreased, it was only a partial improvemet. In the literature review, most of the patients required glucocorticoids combined with cyclophosphamide, azathioprine or rituximab targeting AAV. Fortunately, most of them resulted in a remission within 3 months, which is similar to the treatment response for IgG4-RD. Furthermore, 88.2\% patients with IgG4-RKD could improve renal function with lower serum creatinine levels as serum IgG4 concentration decreased.

It is acknowledged that there are some limitations to this work. There was a lack of histological evaluation of the lung lesion in the case study due to the high risk of biopsy. Besides, the limited availability of detailed data in some literature might also lead to biased perceptions. Future follow-up on imaging changes of lung in the patient should be continued.

\section{Conclusion}

In conclusion, through a case study and the literature review, four common clinicopathologic characteristics will help to alert the clinicians to look for the overlap of both conditions. This study suggests that AAV may overlap with IgG4-RD while presenting atypical manifestations. A common etiology and pathogenesis for both IgG4-RD and AAV should be further explored.

\section{Declarations}

\section{Ethics approval and consent to participate}

This study was approved by the Ethics Committee of the Sun Yat-sen Memorial Hospital, Sun Yat-sen University (SYSEC-KY-KS-2020-080-001).

\section{Consent for publication}

Written consent was obtained from the patient.

\section{Availability of data and materials}

All data generated or analysed during this study are included in this published article.

\section{Competing interests}

The authors declare no competing interest.

\section{Funding}

This work was supported by grants of the National Natural Science Foundation of China (No. 81770709, 81370786), Guangzhou Municipal Science and Technology Project (No. 201904010142), and Guangdong Science and Technology Department (No. 2017B030314026).

\section{Authors' contributions}

Qiongqiong Yang: Research concept and design, final approval of article

Peifen Liang: Writing the article

Wenfang Chen: Critical revision of the article

Shuling Yue: Data analysis and interpretation

Qianqian Han: Collection and assembly of the case data

Litong Zhu: Collection and assembly of the literature data

Jinggao Li: Collection and assembly of the follow-up data of the case

\section{Acknowledgements}

None.

Authors' information 
a Department of Nephrology, Sun Yat-sen Memorial Hospital, Sun Yat-sen University, Guangzhou, 510120 China

${ }^{b}$ Guangdong Provincial Key Laboratory of Malignant Tumor Epigenetics and Gene Regulation, Sun Yat-sen Memorial Hospital, Sun Yat-sen University, Guangzhou, 510120 China

${ }^{c}$ Department of Pathology, The First Affiliated Hospital of Sun Yat-sen University, Guangzhou, 510080 China

d Guangzhou KingMed Center for Clinical Laboratory Co., Ltd, Guangzhou, 510000 China

\section{Abbreviations}

ANCA: antineutrophil cytoplasmic antibody

AAV: antineutrophil cytoplasmic antibody -associated vasculitis

MPO: myeloperoxidase

PR3: proteinase 3

MPA: microscopic polyangiitis

GPA: granulomatosis with polyangiitis

EGPA: eosinophilic granulomatosis with polyangiitis

IgG4-RD: Immunoglobulin G4-related disease

IgG4-RKD: IgG4-related kidney disease

TIN: tubulointerstitial nephritis

CT: computed tomography

CRP: C-reactive protein

ENT: ear, nose and throat

PNS: peripheral nervous system

GN: glomerulonephritis

HPF: high power field

PCs: plasma cells

SF: storiform fibrosis

CGN: crescentic glomerulonephritis

RF: renal function

HPF: high-power field

ENT: Ear, nose and throat

MP: methylprednisolone

GC: glucocorticoids

CTX: cyclophosphamide

AZA: azathioprine

RTX: rituximab

ACR: urine albumin to creactinine ratio

PCR: protein-to-creatinine ratio

PRO: urine protein 
PE: plasmapheresis

Scr: serum creatinine

IF: immunofluorescence

FRA: fibrinogen-related antigen

NA: not available

\section{References}

1. Jennette JC, Falk RJ, Bacon PA, Basu N, Cid MC, Ferrario F, et al. 2012 revised International Chapel Hill Consensus Conference Nomenclature of Vasculitides. Arthritis Rheum. 2013;65(1):1-11.

2. Della-Torre E, Lanzillotta M, Doglioni C. Immunology of IgG4-related disease. Clin Exp Immunol. 2015;181(2):191-206.

3. Cortazar FB, Stone JH. IgG4-related disease and the kidney. Nat Rev Nephrol. 2015;11(10):599-609.

4. Kamisawa T, Zen Y, Pillai S, Stone JH. IgG4-related disease. Lancet. 2015;385(9976):1460-71.

5. Chang SY, Keogh KA, Lewis JE, Ryu JH, Cornell LD, Garrity JA, et al. IgG4-positive plasma cells in granulomatosis with polyangiitis (Wegener's): a clinicopathologic and immunohistochemical study on 43 granulomatosis with polyangiitis and 20 control cases. Hum Pathol. 2013;44(11):2432-7.

6. Danlos FX, Rossi GM, Blockmans D, Emmi G, Kronbichler A, Durupt S, et al. Antineutrophil cytoplasmic antibody-associated vasculitides and IgG4-related disease: A new overlap syndrome. Autoimmun Rev. 2017;16(10):1036-43.

7. Kawashima H, Utsugi A, Shibamiya A, lida K, Mimura N, Ohashi H, et al. Consideration concerning similarities and differences between ANCA-associated vasculitis and IgG-4-related diseases: case series and review of literature. Immunol Res. 2019;67(1):99-107.

8. Khosroshahi A, Wallace ZS, Crowe JL, Akamizu T, Azumi A, Carruthers MN, et al. International Consensus Guidance Statement on the Management and Treatment of IgG4-Related Disease. Arthritis Rheumatol. 2015;67(7):1688-99.

9. Yoo J, Ahn SS, Jung SM, Song JJ, Park YB, Lee SW. No overlap between IgG4-related disease and microscopic polyangiitis and granulomatosis with polyangiitis despite elevated serum IgG4 at diagnosis: a retrospective monocentric study. Clin Rheumatol. 2019;38(4):1147-54.

10. Erden A, Bolek EC, Yardimci KG, Kilic L, Bilgen SA, Karadag O. Do ANCA-associated vasculitides and IgG4-related disease really overlap or not. Int J Rheum Dis. 2019;22(10):1926-32.

11. Umehara H, Okazaki K, Masaki Y, Kawano M, Yamamoto M, Saeki T, et al. Comprehensive diagnostic criteria for lgG4-related disease (IgG4-RD), 2011. Mod Rheumatol. 2012;22(1):21-30.

12. Raissian Y, Nasr SH, Larsen CP, Colvin RB, Smyrk TC, Takahashi N, et al. Diagnosis of IgG4-related tubulointerstitial nephritis. J Am Soc Nephrol. 2011;22(7):1343-52.

13. Salvador F. ANCA associated vasculitis. Eur J Intern Med. 2020;74:18-28.

14. Geetha D, Jefferson JA. ANCA-Associated Vasculitis. Core Curriculum 2020. Am J Kidney Dis. 2020;75(1):124-37.

15. Li ZY, Wang X, Xia X, Yu XJ, Wang SX, Chen W, et al. An overlap of antineutrophil cytoplasmic antibody (ANCA)-associated glomerulonephritis and IgG4related kidney disease. Clin Chim Acta. 2019;501:12-9.

16. Ma Y, Chen L, Xu Y, Han Q, Yu B, Yuan Y, et al. Clinical and pathological features of patients with antineutrophil cytoplasmic antibody-associated vasculitides concomitant with IgG4-related disease. Int J Rheum Dis. 2019;22(12):2143-50.

17. Su T, Yang L, Cui Z, Wang SX, Zhao MH. Concurrent IgG4-related tubulointerstitial nephritis and IgG4 myeloperoxidase-anti-neutrophil cytoplasmic antibody positive crescentic glomerulonephritis: A case report. Med (Baltim). 2017;96(20):e6707.

18. Berden AE, Ferrario F, Hagen EC, Jayne DR, Jennette JC, Joh K, et al. Histopathologic classification of ANCA-associated glomerulonephritis. J Am Soc Nephrol. 2010;21(10):1628-36.

19. Bravais J, Pogliaghi M, Polivka M, Sène D, Roriz M. IgG4-related disease and ANCA positivity: an overlap syndrome. QJM. 2017;110(11):749-50.

20. Massey J. IgG4-related hypertrophic pachymeningitis coexpressing antineutrophil cytoplasmic antibodies. Neurol Neuroimmunol Neuroinflamm. 2017;4(3):e341.

21. Touge H, Tomita K, Yamasaki A, Shimizu E. A case of proteinase 3 anti-neutrophil cytoplasmic antibody (PR3-ANCA) positive/lgG4-related lung disease. Respir Med Case Rep. 2017;20:92-4.

22. Della-Torre E, Lanzillotta M, Campochiaro C, Bozzalla E, Bozzolo E, Bandiera A, et al. Antineutrophil cytoplasmic antibody positivity in IgG4-related disease: A case report and review of the literature. Med (Baltim). 2016;95(34):e4633.

23. Alexandraki KI, Kaltsatou M, Chatzellis E, Goules AV, Boutzios G, Kolomodi D, et al. Hypophysitis in IgG4-Related Disease Associated with p-ANCA Vasculitis. Am J Med. 2016;129(6):e25-7.

24. Ohno K, Matsuda Y, Arai T, Sugihara T, Iga S, Kimura Y. Myeloperoxidase-Antineutrophil Cytoplasmic Antibody-Positive Otitis Media and Rhinosinusitis With Pathological Features of Immunoglobulin G4-Related Disease: A Case Report. Ann Otol Rhinol Laryngol. 2016;125(6):516-21.

25. Tosovský M, Bradna P, Laco J, Podhola M, Soukup T, Brozík J. Case 1-2012: ANCA associated glomerulonephritis in combination with IgG4-positive mediastinal mass in a patient with ankylosing spondylitis treated with TNF alpha inhibitors. Acta Medica (Hradec Kralove). 2012;55(1):42-6. 
26. Hanioka Y, Yamagami K, Yoshioka K, Nakamura T, Kishida M, Nakamura T, et al. Churg-Strauss syndrome concomitant with chronic symmetrical dacryoadenitis suggesting Mikulicz's disease. Intern Med. 2012;51(17):2457-61.

27. Watanabe T, Kanda M, Fukaya S, Ogawa Y, Akikawa K. Rapidly progressive glomerulonephritis caused by overlap syndrome of IgG4-related tubulointerstitial nephritis and myeloperoxidase-antineutrophil cytoplasmic antibody-associated necrotising glomerulonephritis. Clin Exp Rheumatol. 2018;36(Suppl 111(2):172-73.

28. Wang GQ, Chen YP, Cheng H, Xu XY, Sun LJ, Dong HR. Antineutrophil cytoplasmic antibody and/or antiglomerular basement membrane antibody associated crescentic glomerulonephritis in combination with IgG4-related tubulointerstitial nephritis. Clin Exp Rheumatol. 2019;37(2):279-85.

29. Zhang P, Cornell LD. IgG4-Related Tubulointerstitial Nephritis. Adv Chronic Kidney Dis. 2017;24(2):94-100.

30. Holland M, Hewins P, Goodall M, Adu D, Jefferis R, Savage CO. Anti-neutrophil cytoplasm antibody IgG subclasses in Wegener's granulomatosis: a possible pathogenic role for the IgG4 subclass. Clin Exp Immunol. 2004;138(1):183-92.

\section{Tables}

Table 1. Comparison of features of AAV vs. IgG4-RD vs. the case.

\begin{tabular}{|c|c|c|c|c|}
\hline & $\operatorname{AAV}^{[1,13,14]}$ & $\operatorname{lgG} 4-\mathrm{RD}^{[3,4]}$ & & The case \\
\hline $\begin{array}{l}\text { Clinical } \\
\text { symtome }\end{array}$ & $\begin{array}{l}\text { Fatigue, fever, weight } \\
\text { loss,arthralgias, } \\
\text { rhinosinusitis, cough, } \\
\text { dysphea, conductive } \\
\text { deafness, urinary } \\
\text { abnormalities, renal } \\
\text { insufficiency, purpura, } \\
\text { neurologic dysfunction }\end{array}$ & $\begin{array}{l}\text { Subacute development of a } \\
\text { mass, pain eyelid, asthma, } \\
\text { allergy, weight loss, fatigue, } \\
\text { submandibular and/or parotid } \\
\text { gland enlargement, cough, } \\
\text { dysphea, renal insufficiency }\end{array}$ & & $\begin{array}{l}\text { Cough, hemoptysis, } \\
\text { anorexia, fatigue, } \\
\text { ear stuffiness, renal } \\
\text { insufficiency }\end{array}$ \\
\hline $\begin{array}{l}\text { Organ } \\
\text { manifestations }\end{array}$ & $\begin{array}{l}\text { Lung: } \\
\text { pulmonary capillaritis, } \\
\text { patchy or diffuse opacities, } \\
\text { fleeting pulmonary } \\
\text { infiltrates, pulmonary } \\
\text { hemorrhage, hilar } \\
\text { adenopathy } \\
\text { Kidney: } \\
\text { necrotizing and crescentic } \\
\text { GN ENT: } \\
\text { nasal crusting, } \\
\text { sinusitis, oral and /or nasal } \\
\text { ulcers, conductive and /or } \\
\text { sensorineural hearing loss }\end{array}$ & $\begin{array}{l}\text { Lung: pulmonary } \\
\text { nodules or inflammatory } \\
\text { pseudotumor, central airway } \\
\text { disease, localized or } \\
\text { diffuse interstitial pneumonia, } \\
\text { pleuritis, pleural } \\
\text { nodular thickening, } \\
\text { ground-glass opacities } \\
\text { Kidney: } \\
\text { tubulointerstitial } \\
\text { nephritis membranous } \\
\text { glomerulonephropathy } \\
\text { bilateral renal enlargement } \\
\text { advanced renal dysfunction }\end{array}$ & $\begin{array}{l}\text { Ears, nose, and sinuses: nasal } \\
\text { polyps allergic rhinitis } \\
\text { asthma } \\
\text { chronic sinusitis eosinophilia nasal } \\
\text { obstruction }\end{array}$ & $\begin{array}{l}\text { Lung: } \\
\text { diffuse lesions in both } \\
\text { lungs, ground-glass } \\
\text { opacities in the lower } \\
\text { lungs } \\
\text { pulmonary } \\
\text { nodules } \\
\text { Kidney: } \\
\text { pauci-immune } \\
\text { crescentic GN } \\
\text { IgG4-positive plasma } \\
\text { cell-enriched TIN } \\
\\
\text { Ears, nose, and } \\
\text { sinuses: } \\
\text { hearing loss mixed } \\
\text { middle ear } \\
\text { mastoiditis } \\
\text { paranasal sinusitis }\end{array}$ \\
\hline $\begin{array}{l}\text { Serologic } \\
\text { characteristics }\end{array}$ & $\begin{array}{l}\text { ANCA positive } \\
\text { High levels of C-reactive } \\
\text { protein Normochromic } \\
\text { normocytic anemia }\end{array}$ & $\begin{array}{l}\text { Serum IgG4 level > } 135 \mathrm{mg} / \mathrm{dL} \\
\text { Hypocomplementaemia } \\
\text { Peripheral-blood } \\
\text { eosinophilia } \\
\text { High concentrations of IgE }\end{array}$ & & $\begin{array}{l}\text { Increased MPO- } \\
\text { ANCA Serum } \\
\text { lgG4 level > } \\
135 \mathrm{mg} / \mathrm{dL} \\
\text { High concentrations of } \\
\text { lgE }\end{array}$ \\
\hline Urinalysis & $\begin{array}{l}\text { Hematuria } \\
\text { Erythrocyte cast } \\
\text { Subnephrotic proteinuria }\end{array}$ & $\begin{array}{l}\text { Subnephrotic proteinuria } \\
\text { Mild haematuria }\end{array}$ & & $\begin{array}{l}\text { Subnephrotic } \\
\text { proteinuria } \\
\text { haematuria }\end{array}$ \\
\hline Histology & Necrotizing vasculitis & $\begin{array}{l}\text { Lymphoplasmamacytic } \\
\text { infiltrate Storiform } \\
\text { fibrosis Obliterative } \\
\text { phlebitis }\end{array}$ & & $\begin{array}{l}\text { Pauci-immune } \\
\text { crescentic GN IgG4- } \\
\text { positive plasma cell- } \\
\text { enriched TIN }\end{array}$ \\
\hline
\end{tabular}

$A A V=A N C A$-associated vasculitis, IgG4-RD=lgG4-related disease, $M P O=$ myeloperoxidase, $T I N=$ tubulointerstitial nephritis, ENT=Ear, nose and throat, GN= glomerulonephritis

Table 2. Reports in the literature of patients combined biopsy-proven IgG4-RD and AAV. 


\begin{tabular}{|c|c|c|c|c|c|c|c|c|c|c|}
\hline Cases & $\begin{array}{l}\text { Age } \\
\text { (y) }\end{array}$ & Sex & $\begin{array}{l}\text { CRP } \\
(\mathrm{mg} / \mathrm{dl})\end{array}$ & $\begin{array}{l}\text { ANCA } \\
(\mathrm{U} / \mathrm{ml})\end{array}$ & $\begin{array}{l}\lg \mathrm{G} 4 \\
(\mathrm{mg} / \mathrm{dl})\end{array}$ & $\begin{array}{l}\text { AAV Organ } \\
\text { involvement }\end{array}$ & $\begin{array}{l}\text { IgG4-RD Organ } \\
\text { involvement }\end{array}$ & Biopsy & Treatment & Outcome \\
\hline Bravais $^{[19]}$ & 31 & $\mathrm{~F}$ & 17.9 & $\begin{array}{l}\text { MPO- } \\
\text { ANCA } \\
3.4 \mathrm{UA}\end{array}$ & 227 & ENT & Lung & $\begin{array}{l}\text { Vocal cord } \\
\text { granuloma: } \\
\text { non-diagnostic } \\
\text { Lung: SF, } \\
\text { IgG4+PCs >20/HPF }\end{array}$ & $\begin{array}{l}\text { MP pulse, } \\
\text { GC }\end{array}$ & $\begin{array}{l}\text { General } \\
\text { condition } \\
\text { improved } \\
\text { promptly }\end{array}$ \\
\hline Massey ${ }^{[20]}$ & 70 & M & NA & $\begin{array}{l}\text { p- } \\
\text { ANCA } \\
(1: 80) \\
\text { MPO- } \\
\text { ANCA: } \\
30\end{array}$ & 233 & $\begin{array}{l}\text { Dura, } \\
\text { retroperitoneal } \\
\text { lymph nodes }\end{array}$ & Lung & $\begin{array}{l}\text { Dura: SF, hyper- } \\
\text { trophic fibrotic tissue } \\
\text { lgG4+PCs>50 HPF }\end{array}$ & $\begin{array}{l}\text { MP pulse, } \\
\text { GC }\end{array}$ & $\begin{array}{l}\text { Repeat brain MRI } \\
\text { demonstrated } \\
\text { mild } \\
\text { improvement } \\
\text { after } 3 \text { months. }\end{array}$ \\
\hline Touge $^{[21]}$ & 61 & M & 12.3 & $\begin{array}{l}\text { PR3- } \\
\text { ANCA } \\
246\end{array}$ & 258 & $\begin{array}{l}\text { Lung, } \\
\text { mediastinal } \\
\text { lymph nodes, }\end{array}$ & Lung & $\begin{array}{l}\text { Lung: Inflammatory } \\
\text { granuloma } \\
\text { formation, } \\
\text { IgG4+PCs }>20 / \mathrm{HPF}\end{array}$ & GC & $\begin{array}{l}\text { Pseudo-tumor } \\
\text { and right pleural } \\
\text { effusion reduced } \\
\text { after } 1 \text { month. }\end{array}$ \\
\hline $\begin{array}{l}\text { Della- } \\
\text { Torre }^{[22]}\end{array}$ & 52 & $\mathrm{~F}$ & Normal & $\begin{array}{l}\text { C- } \\
\text { ANCA } \\
\text { (PR3 } \\
423)\end{array}$ & 253 & Lung & Skin, lung & $\begin{array}{l}\text { Lacrimal gland: SF } \\
\text { lgG4/lgG PCs }>40 \% \text {, } \\
\text { Lung: necrotizing } \\
\text { granuloma, } \\
\text { leukocytoclastic } \\
\text { vasculitis. }\end{array}$ & GC, RTX & $\begin{array}{l}\text { Orbital and lung } \\
\text { lesions resolved } \\
\text { after } 6 \text { months }\end{array}$ \\
\hline $\begin{array}{l}\text { Alexandraki } \\
\text { [23] }\end{array}$ & 38 & M & 16.7 & $\begin{array}{l}\text { p- } \\
\text { ANCA } \\
\text { (MPO } \\
1: 24)\end{array}$ & 377 & Skin, lung & $\begin{array}{l}\text { Pituitary gland, } \\
\text { orbit, lung }\end{array}$ & $\begin{array}{l}\text { Orbit: SF, } \\
\text { IgG } 4 / \operatorname{lgG} P C s>50 \% \text {, } \\
\text { Skin: } \\
\text { leukocytoclastic } \\
\text { vasculitis }\end{array}$ & $\begin{array}{l}\text { GC, AZA, } \\
\text { RTX }\end{array}$ & $\begin{array}{l}\text { Skin and lung } \\
\text { lesions improved } \\
\text { after } 8 \text { months }\end{array}$ \\
\hline Ohno ${ }^{[24]}$ & 73 & M & 2.63 & $\begin{array}{l}\text { MPO- } \\
\text { ANCA } \\
8.3\end{array}$ & 249 & Kidney & $\begin{array}{l}\text { Ear, nose, } \\
\text { sinuses }\end{array}$ & $\begin{array}{l}\text { Inferior turbinate } \\
\text { mucosa: SF, } \\
\text { IgG4+PCs =30/HPF, } \\
\text { IgG4/IgG PCs =42\%区 } \\
\text { Kidney: mesangial } \\
\text { proliferative, } \\
\text { glomerulosclerosis }\end{array}$ & $\mathrm{GC}, \mathrm{AZA}$ & $\begin{array}{l}\text { Sinonasal } \\
\text { findings, } \\
\text { proteinuria had } \\
\text { normalized after } \\
1 \text { month; } \\
\text { Relapse after } 2 \\
\text { months; }\end{array}$ \\
\hline Tosovsky ${ }^{[25]}$ & 47 & M & 11 & $\begin{array}{l}\text { C- } \\
\text { ANCA } \\
\text { (PR3 } \\
136.8)\end{array}$ & 470 & Kidney & Mediastinum & $\begin{array}{l}\text { Mediastinal mass: } \\
\text { SF, } \\
\text { IgG4/IgG PCs =50\%, } \\
\text { Kidney: necrotizing } \\
\text { glomerulonephritis } \\
\text { and cellular } \\
\text { crescents }\end{array}$ & $\begin{array}{l}\text { MP pulse, } \\
\text { GC, CTX }\end{array}$ & $\begin{array}{l}\text { RF improved, } \\
\text { mediastinal } \\
\text { mass became } \\
\text { smaller (Scr from } \\
212 \text { to } \\
116 \mu \mathrm{mol} / \mathrm{L})\end{array}$ \\
\hline Hanioka $^{[26]}$ & 72 & M & 2.32 & $\begin{array}{l}\text { p- } \\
\text { ANCA } \\
\text { (MPO } \\
758)\end{array}$ & 343 & $\begin{array}{l}\text { Lung, skin, } \\
\text { nerve }\end{array}$ & $\begin{array}{l}\text { Lacrimal } \\
\text { gland, } \\
\text { submandibular } \\
\text { gland, } \\
\text { nasal mucosa }\end{array}$ & $\begin{array}{l}\text { Nasal mucosa: SF, } \\
\text { IgG4/IgG PCs } ₫ 40 \% \\
\text { Skin: } \\
\text { leukocytoclastic } \\
\text { vasculitis with } \\
\text { eosinophilic } \\
\text { infiltration }\end{array}$ & $\mathrm{GC}$ & $\begin{array}{l}\text { lachrymal gland } \\
\text { swelling } \\
\text { improved after } \\
67 \text { days }\end{array}$ \\
\hline
\end{tabular}

ANCA=antineutrophils cytoplasmic antibody, AAV=ANCA-associated vasculitis, HPF=high power field, lgG4-RD=lgG4-related disease, $M P O=m y e l o p e r o x i d a s e$, $P R 3=$ proteinase 3, PCs=plasma cells, $S F=$ storiform fibrosis, CGN=crescentic glomerulonephritis, RF=renal function, HPF=high-power field, ENT=Ear, nose and throat, $M P=$ methylprednisolone, $G C=$ glucocorticoids, $C T X=$ cyclophosphamide, $A Z A=$ azathioprine, $R T X=r i t u x i m a b \square N A=n o t$ available.

Table 3. Reports in the literature of patients combined biopsy-proven IgG4-RKD and AAV. 


\begin{tabular}{|c|c|c|c|c|c|c|c|c|c|c|c|}
\hline Cases & $\begin{array}{l}\text { No. } \\
\text { of } \\
\text { cases }\end{array}$ & $\mathrm{M} / \mathrm{F}$ & $\begin{array}{l}\text { Age } \\
(y)\end{array}$ & $\begin{array}{l}\text { CRP } \\
(\mathrm{mg} / \mathrm{dl})\end{array}$ & $\begin{array}{l}\text { Scr } \\
(\mu \mathrm{mol} / \mathrm{L})\end{array}$ & $\begin{array}{l}\text { Hematuria } \\
\text { (cells/HPF) }\end{array}$ & $\begin{array}{l}\text { Proteinuria } \\
\text { 『g/24h } \rrbracket\end{array}$ & $\begin{array}{l}\text { ANCA } \\
(\mathrm{N}, \\
\mathrm{U} / \mathrm{ml})\end{array}$ & $\begin{array}{l}\lg G 4 \\
(\mathrm{mg} / \mathrm{dl})\end{array}$ & $\begin{array}{l}\text { AAV Organ } \\
\text { involvement }\end{array}$ & $\begin{array}{l}\text { IgG4-RD } \\
\text { Organ } \\
\text { involvem }\end{array}$ \\
\hline $\mathrm{Li}^{[15]}$ & 19 & $12 / 7$ & $\begin{array}{l}62.8 \\
\pm 9.4\end{array}$ & NA & $320.9 \pm 191.4$ & $\begin{array}{l}90-5 \\
35-15 \\
4 ه 15\end{array}$ & NA & $\begin{array}{l}\text { 18MPO- } \\
\text { ANCA } \\
\text { 1PR3- } \\
\text { ANCA }\end{array}$ & $427.2 \pm 244.0$ & $\begin{array}{l}\text { kidney, lung, } \\
\text { eye, ENT, } \\
\text { PNS, GT }\end{array}$ & $\begin{array}{l}\text { kidney, lu } \\
\text { lymph } \\
\text { glands, } \\
\text { pancreas }\end{array}$ \\
\hline $\mathrm{Ma}^{[16]}$ & 10 & $7 / 3$ & $\begin{array}{l}62.9 \\
\pm \\
11.0\end{array}$ & $\begin{array}{l}5.05 \\
(0.72- \\
8.73)\end{array}$ & $\begin{array}{l}289.5 \pm \\
234.3\end{array}$ & NA & $1.9 \pm 1.1$ & $\begin{array}{l}\text { 10MPO- } \\
\text { ANCA }\end{array}$ & $368.4 \pm 144.2$ & \multicolumn{2}{|c|}{$\begin{array}{l}\text { kidney, lacrimal glands, } \\
\text { lymph glands, lung, } \\
\text { Pancreas (unspecified to } \\
\text { AAV or lgG4-RD) }\end{array}$} \\
\hline Kawashima $^{[7]}$ & 1 & $\mathrm{~F}$ & 63 & 6.4 & 118.5 & $5-9$ & nagative & negative & 407.0 & $\begin{array}{l}\text { Lung, dura } \\
\text { mater, } \\
\text { maxillary } \\
\text { sinusitis, } \\
\text { ear }\end{array}$ & kidneys \\
\hline Watanabe ${ }^{[27]}$ & 1 & $M$ & 67 & NA & 366 & $20-29$ & 1.3 & $\begin{array}{l}\text { MPO- } \\
\text { ANCA } \\
280\end{array}$ & 378 & kidney & $\begin{array}{l}\text { Iliacartery } \\
\text { kidney }\end{array}$ \\
\hline G.Q.Wang ${ }^{[28]}$ & 1 & M & 56 & NA & 384.5 & $10-15$ & 2.38 & $\begin{array}{l}\text { p-ANCA } \\
\text { (MPO } \\
168.0)\end{array}$ & 732 & kidney & kidney \\
\hline G.Q.Wang ${ }^{[28]}$ & 1 & $\mathrm{~F}$ & 31 & 4.13 & 274.7 & $10-15$ & 1.1 & $\begin{array}{l}\text { p-ANCA } \\
(\mathrm{MPO} \\
95.3)\end{array}$ & 426 & kidney & kidney \\
\hline $\mathrm{Su}^{[17]}$ & 1 & $M$ & 42 & 7.24 & 157 & $10-15$ & ACR $125.5 \mathrm{mg} / \mathrm{g}$ & $\begin{array}{l}\text { p-ANCA } \\
\text { (MPO } \\
>200)\end{array}$ & 183 & $\begin{array}{l}\text { paranasal } \\
\text { sinus } \\
\text { kidney }\end{array}$ & $\begin{array}{l}\text { Pancreas } \\
\text { kidney }\end{array}$ \\
\hline
\end{tabular}

ANCA=antineutrophils cytoplasmic antibody, $A A V=A N C A$-associated vasculitis, lgG4-RKD=lgG4-related kidney disease, MPO=myeloperoxidase, $P R 3=$ proteinase $3, P N S=$ peripheral nervous system, $G T=$ gastrointestinal tract, $T I N=$ tubulointerstitial nephritis, $A C R=u r i n e$ albumin to creactinine ratio, proteinto-creatinine ratio $=P C R, P R O=$ urine protein, $M P=$ methylprednisolone, $G C=$ glucocorticoids, $C T X=$ cyclophosphamide, $A Z A=a z a t h i o p r i n e, R T X=r i t u x i m a b \square$ $P E=$ plasmapheresis $\square G N=$ glomerulonephritis, $R F=$ renal function, $S c r=$ serum creatinine, $N A=$ not available.

Table 4. Renal biopsy findings of ANCA-GN and IgG4-RKD. 


\begin{tabular}{|c|c|c|c|c|c|c|c|c|}
\hline Cases & $\begin{array}{l}\text { No. of } \\
\text { cases }\end{array}$ & $\begin{array}{l}\text { Normal } \\
\text { glomeruli } \\
\text { (no. / \%) }\end{array}$ & $\begin{array}{l}\text { Crescent } \\
\text { (no. / \%) }\end{array}$ & $\begin{array}{l}\text { Global } \\
\text { glomerulosclerosis } \\
(\%)\end{array}$ & $\begin{array}{l}\text { Fibrinoid } \\
\text { necrosis } \\
\text { (no. / \%, +/-) }\end{array}$ & IF & $\begin{array}{l}\text { IgG4+PCs } \\
\text { infiltrates }\end{array}$ & $\begin{array}{l}\text { Storiform } \\
\text { fibrosis }\end{array}$ \\
\hline $\mathrm{Li}^{[15]}$ & 19 & $\begin{array}{l}47.3 \% \\
\pm 24.2 \%\end{array}$ & $\begin{array}{l}41.2 \% \\
\pm 25.4 \%\end{array}$ & NA & $5 / 26 \%$ & NA & $\begin{array}{l}19 \mathrm{lgG} 4+\mathrm{PCs} \\
>10 / \mathrm{HPF}\end{array}$ & $3+$ \\
\hline $\mathrm{Ma}^{[16]}$ & 10 & NA & $\begin{array}{l}23.2 \% \\
\pm 15.4 \%\end{array}$ & $36.6 \% \pm 25.7 \%$ & $7 / 70 \%$ & NA & $\begin{array}{l}8 \mathrm{lgG} 4+\mathrm{PCs} \\
>10 / \mathrm{HPF}\end{array}$ & $9+$ \\
\hline $\begin{array}{l}\text { Watanabe } \\
\mathrm{T}^{[27]}\end{array}$ & 1 & $9 / 75 \%$ & 0 & 0 & + & NA & $\operatorname{lgG} 4+P C s>50 / H P F$ & + \\
\hline G.Q.Wang ${ }^{[28]}$ & 1 & $2 / 12.5 \%$ & $14 / 87.5 \%$ & 0 & - & $\begin{array}{l}\text { lgG+++++++++, } \\
\text { FRA++ }\end{array}$ & $\begin{array}{l}\text { IgG4+PCs } \\
>10 / \mathrm{HPF}\end{array}$ & + \\
\hline G.Q.Wang ${ }^{[28]}$ & 1 & $5 / 31.2 \%$ & $11 / 68.5 \%$ & 0 & + & - & $\begin{array}{l}\text { IgG4+PCs } \\
>10 / \mathrm{HPF}\end{array}$ & + \\
\hline $\mathrm{Su}^{[17]}$ & 1 & $6 / 20 \%$ & $24 / 80 \%$ & 0 & + & $\begin{array}{l}\text { C3+-++, } \\
\text { FRA+-++ }\end{array}$ & $\begin{array}{l}\operatorname{lgG} 4 / \operatorname{lgg} \\
\mathrm{PCs}>40 \%\end{array}$ & + \\
\hline
\end{tabular}

ANCA=antineutrophils cytoplasmic antibody, AAV=ANCA-associated vasculitis, IgG4-RKD=IgG4-related kidney disease, IF=immunofluorescence, $P C s=$ plasma cells, FRA=fibrinogen-related antigen, HPF=high power field, NA=not available

\section{Figures}
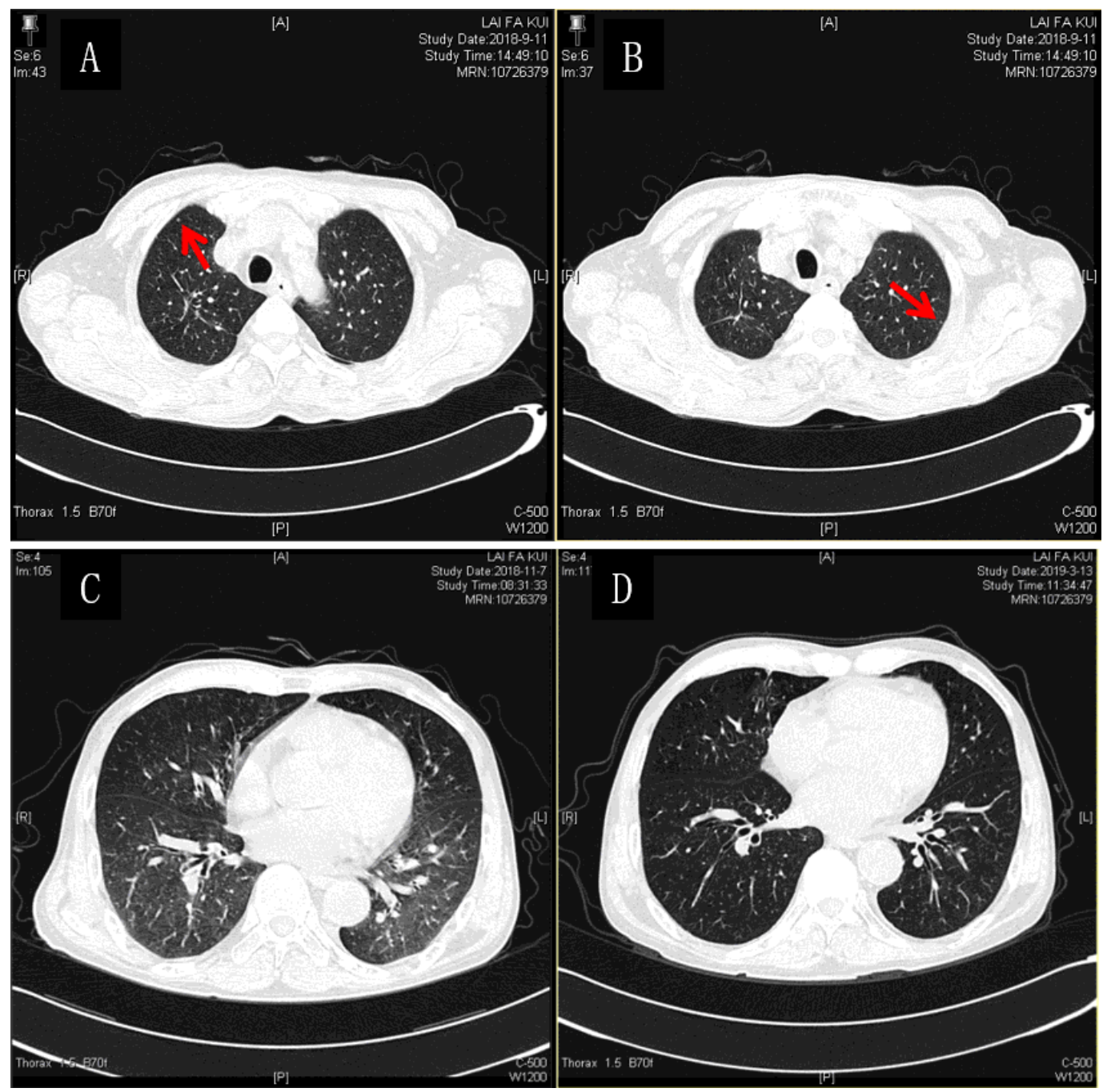

Figure 1 
Radiological findings of involvement in lung. A and B, multiple subpleural small nodules observed in bilateral lungs (arrow). C and D, Bilateral ground-glass opacities displayed in the lower lung before (C) and after treatment (D).
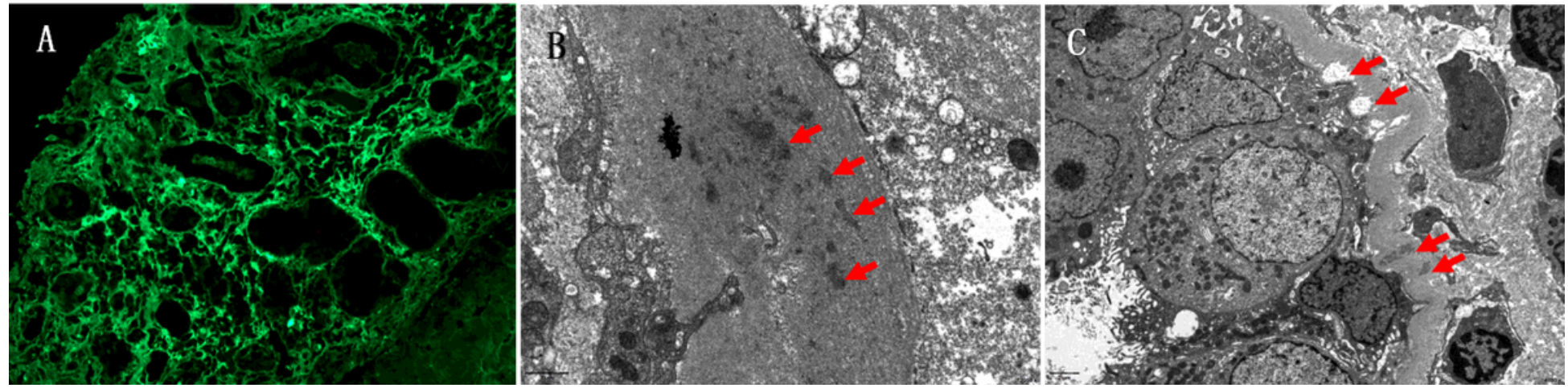

\section{Figure 2}

Pathological findings in the tubular basement membrane. A, By immunofluorescence, granular tubular basement membrane staining for IgG is seen ( $\times 200)$. B, electron-dense without substructure deposits in the tubular basement membrane (× 12000). C, electron-dense without substructure deposits and absorbs in the tubular basement membrane $(\times 12000)$.
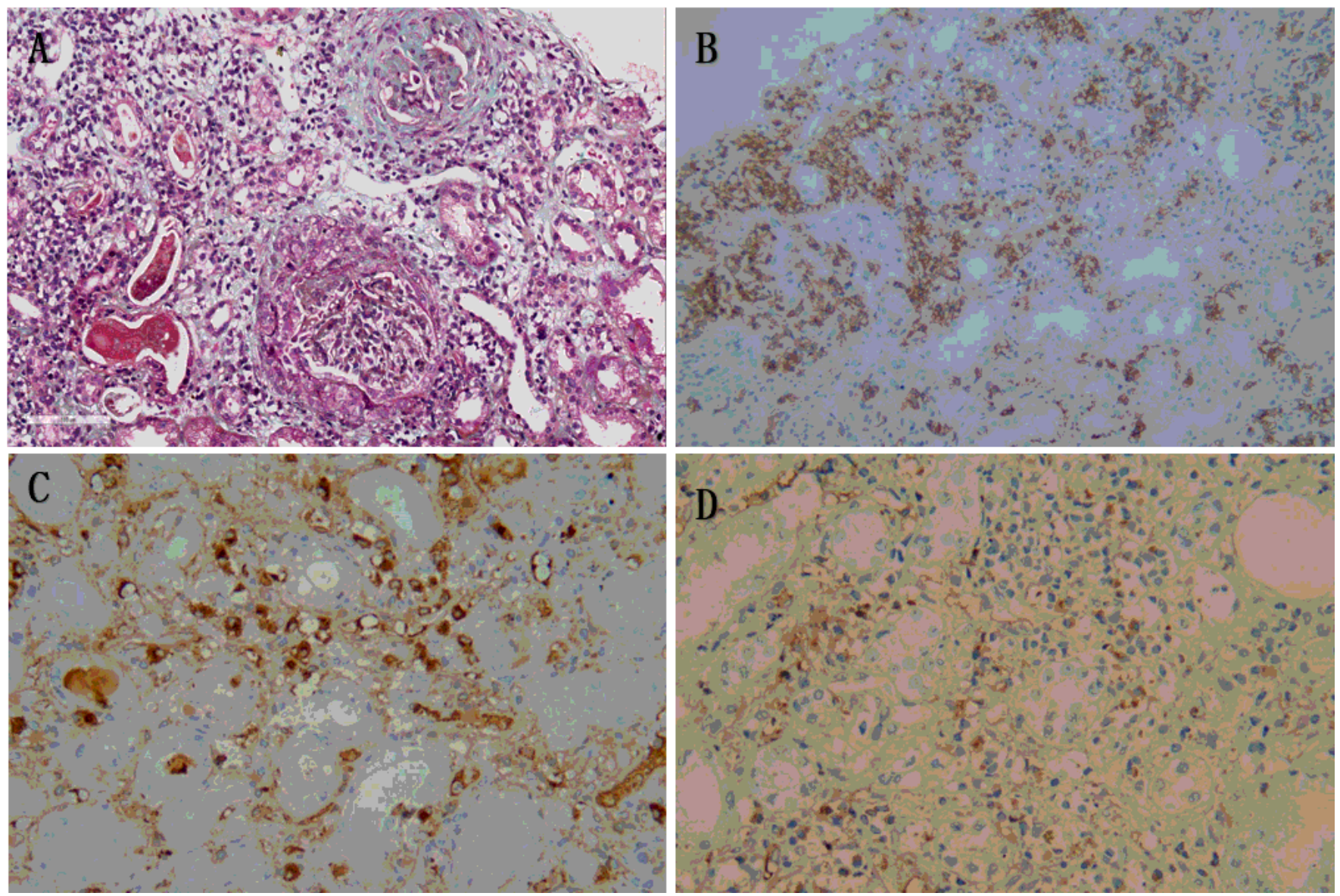

\section{Figure 3}

Pathological findings in the renal biopsy specimen. A, crescentic glomerulonephritis (MASSON, $\times 200)$. B, CD38-positive plasma cells infiltrate in the renal interstitium ( $\times 400)$. C, IgG4-positive plasma cells in the renal interstitium ( $\times 400)$. D, IgG-positive plasma cells in the renal interstitium $(\times 400)$. 
A
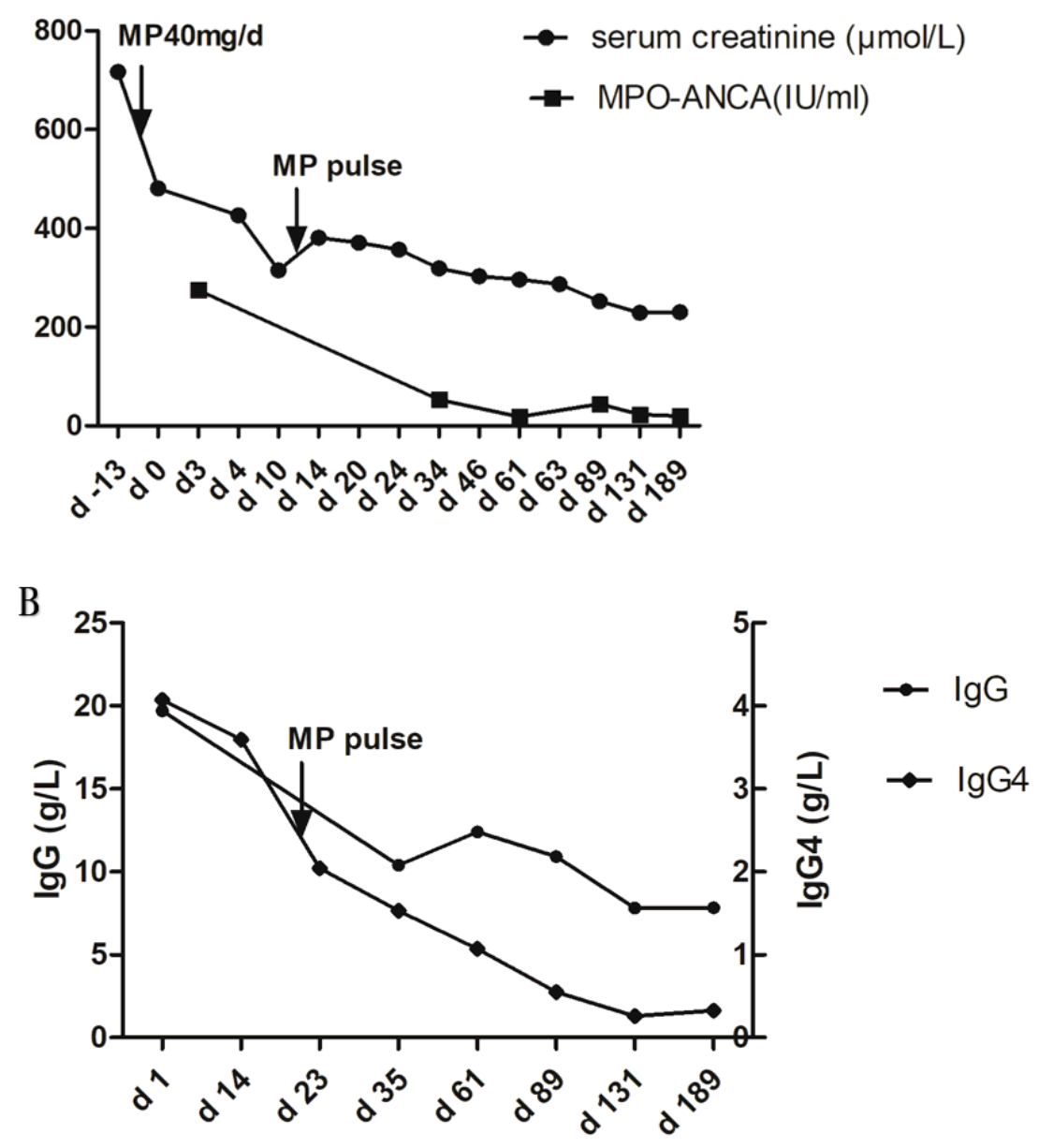

Figure 4

Changes in the levels of parameters during therapy and follow-up. A, Changes in the levels of serum creatinine and MPO-ANCA. B, Changes in the levels of serum $\lg G$ and $\lg G$. 